\title{
Model Development of the Material Tracking System for High-Rise Building Construction Project Using RFID Technology
}

\author{
Soon-Wook Kwon*, Min-Woo Lee*, Jae-Goo Han*, Moon-Young Cho*, Jae-Woo Park* \\ * Construction Engineering \& Management Research Department, Korea Institute of \\ Construction Technology, Goyang-Si, Gyeonggi-Do, 411-712, Republic of Korea (e-mail: \\ swkwon@kict.re.kr )
}

\begin{abstract}
Current study of material management on construction site insists that the ratio of material handling costs to total project costs varies in 30 to $80 \%$ depends on the type of construction and the cost of materials [1]. Site layout planning and material management are fundamental to reduce materials handling and re-handling costs and to enhance the efficiency of construction operation for high-rise building. Moreover, these are useful to control planned construction schedule by eliminating the factors related to spatial conflicts due to limited space. There is a need for tracking and controlling effectively material loading and delivery time especially during finishing-work phases to eliminate the need for laydown space on site. Hence, it is essential for monitoring of relevant information regarding material procurement in construction sites and it is the key factor for successful site control and adopting Just-in-Time concept in high-rise building construction. Eventually, the material tracking system is very important for requisition, delivery, and movement of the materials in time. In this paper, the material tracking system using RFID (Radio Frequency IDentification) technique is introduced. Using this system, the materials are going to be efficiently tracked and managed in finishing-work phases.
\end{abstract}

Keywords : RFID, high-rise building, finishing work phases, procurement, material tracking

\section{INTRODUCTION}

As on-site stockyard is limited in high-rise building construction underway downtown and transportation of materials in large quantity and movement of lots of crews and equipment need to be made in a confined environment, it is always difficult to allocate space for storing and moving material. As a result, tracking and delivery of material in time for delaying construction process has become critical to efficient management of construction resources. Notably, as finishing-work stage requires resources in largest quantity compared to other construction stages, there is a pending need for arrangement by which delivery of materials may be monitored real time to facilitate construction progress.

The higher the building is, the more critical it is that various materials be delivered and stocked in time as different processes are required to be in progress at the same time. In addition, information generated at various steps of construction workflow with regard to design or construction takes a lot of time to reach sub-contractors working on site and the speed of communication has an absolute impact on construction progress.

To address the issue, a systematic support for material management and control of materials needs to be provided, which calls for a material tracking system designed to ensure just-in-time delivery of required materials in right quantity and to provide constant monitoring capability. This research has attempted to propose a system development model intended to provide efficient tracking capability based on RFID (Radio Frequency IDentification) technology to support material procurement in finishing work stage of high-rise building construction projects.

Scope of this research was limited to proposing a prototype model of material tracking system for ceiling using RFID technology. Following methodology was applied to analyze the characteristics of ceiling material procurement flow and identify processes to which RFID technology could be applied:

- Perform literature surveys and interviews with RFID vendors to find out RFID system components, their technical features and application status

- Examine ceiling material procurement flow by studying literatures and interviewing experts

- Propose an approach to develop prototype model of material tracking system based on RFID technologies and aligned to characteristics of ceiling materials.

\section{Literature Survey}

\subsection{RFID technology}

RFID refers to a systematic arrangement where chips are embedded in tags attached to products to store the information created at various steps of material procurement process including purchase order placement, production, procurement, storing and site delivery. Readers equipped with own antenna 
read data stored in them and the chips are integrated with information management system through mobile communication network interface.

As illustrated in Figure 1, RFID system comprises of antenna-attached reader, an antenna capable of transmitting/receiving radio frequency, data-storing tag and server exchanging data in accordance with a protocol through communication network.

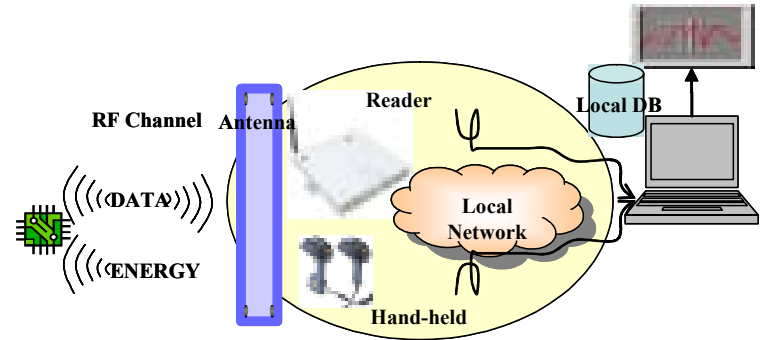

Figure 1. RFID System Configuration

Depending on whether supply of power is required or not, RFID tag is classified into active type that needs its own power supply or passive type that is activated by electro-magnetic field of reader without relying on inter or external power supply. The former may save power required by reader and ensure longer recognition range while it is limited in runtime and more expensive than the latter. On the other hand, passive type is lighter and less expensive than active type and semi-permanent. But, its reading range is short and requires reader to consume more power. Tags are also classified by their frequency band as tag characteristics vary, depending on radio frequencies used. Frequency band in most use are: $125.134 \mathrm{KHz}, 13.56 \mathrm{MHz}, 433 \mathrm{MHz}, 860 \sim 960 \mathrm{MHz}$, and $2.45 \mathrm{GHz}$.

\subsection{Limitations of RFID}

\section{1) Non-Standardization \& High Cost}

Readers, tags and SW applications available in the market are hardly compatible with each other. Each vendor is concerned that its own technical result may be disclosed to competitors. Accordingly, compatibility issues across RFID frequency ranges, components, active/passive tags, data structure, data classification \& representation, communication protocol between tag and reader are the bone of contention in a debate on standardization of RFID systems.

Moreover, utilization of RFID system is not commonly available for its high cost. It is difficult to expand the scope of RFID application at the moment for price of tag is still too high, but it is believed to become affordable in several years given the rapid development of applicable technologies.

2) Metal \& Frequency Interference
Obstructions to recognition of information stored in RFID tag are broken down to two categories. First of all, metallic materials reflect RF signal, interfering tag antenna with radio reception. Next is the assignment of frequency band which is delayed at the moment, obstructing spread of RFID products. In other words, it is yet difficult to discern various data in the same frequency band. Governments are trying to define assignable frequency band in legislation. In addition, rubber or liquid such as water also interferes with reception of RF signal.

\subsection{Application of RFID Technology in} Constructions

A domestic construction contractor implemented a labor and material (ready mixed concrete) tracking system utilizing bar-code platform which is a predecessor of RFID technology and saved about KRW 4.1 billion in direct and indirect costs and 1 month in construction schedule, which implies that RFID technology that is more advanced than barcode approach may ensure better returns when applied.

The U.S. Carnegie Mellon University proposed a precast concrete material tracking system utilizing RFID platform [2]. $\$ 178,000$ (equal to 7,120 working hours) was invested in RFID system implementation in total, but time spent on tracking materials was cut in half. The system is also thought to lead to additional cost saving as cost overrun incurred by delays in material delivery is estimated at $\$ 60,000$ per supplier every year.

A site test of the Construction Industry Institute (CII) of the U.S. conducted in the Red Hills Construction Project of Bechtel found out that RFID technology saved time spent on locating and tracking pipe supports and hangers by 30\% (159 min./100 hangers) [3]. In other cases, RFID technology was pilot tested to locate and track compressed gas cylinder, small tools or construction equipment and feasibility of applying RFID systems to detect fatigues of excessive stress to concrete and steel components to support structural maintenance is being studied.

RFID technology is not widely used in the domestic construction industry. As mentioned before, some general contractors applied bar-code technology to labor and material management in a limited scope to a certain degree of success, but limitations of bar-code technology such as data recognition error or limited reading range revealed several problems in actual implementation. However, radio frequency recognition technologies such RFID systems may promise significant returns on investment if their advantages are properly utilized, 
which will mark a great turning point in application of IT technology in construction industry.

\subsection{Application Procedure of RFID}

Users of RFID system must base its design on major considerations at each stage of system implementation. First of all, purpose of RFID implementation must be clarified whether it is time saving, material tracking or equipment control, etc. Next, it should be determined whether the system would provide simply Read Only (R/O) or Read/Write (R/W) function would be required. The latter may be desirable if tag data contents are to be modified after implementation from time to time and the former may be acceptable if that is not the case. Then, database capacity should be defined. If data storage capacity is less than $2 \mathrm{kbytes}, \mathrm{R} / \mathrm{O}$ system is recommended and $\mathrm{R} / \mathrm{W}$ system if it is the other way around. In addition, potential interferences with RF signal need to be considered in system design [4].

Table 1. Important Considerations on RFID Technology [3]

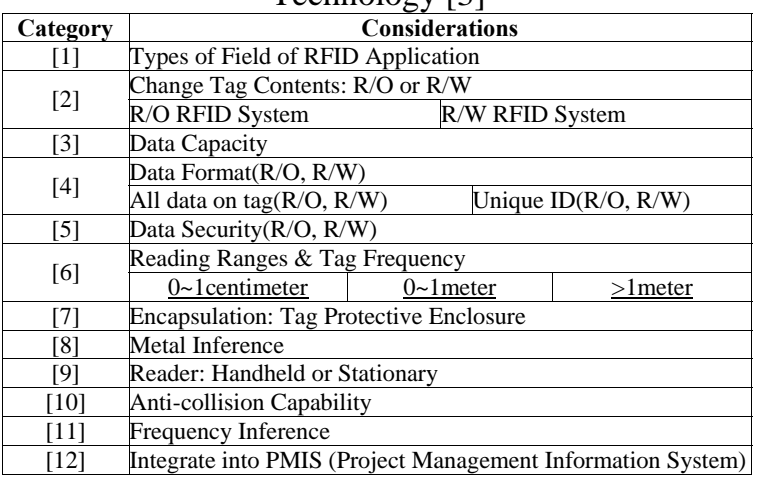

Notably, metals interfere with RF signal easily and frequency range is also critical, as the system is required to discern lots of signals contained in a single frequency band. In addition, whether to use fixed reader or portable type and whether RFID system needs to be integrated with project management information system (PMIS) should be reflected on system design (Table 1).

\subsection{Material Management Process in Construction}

\section{1) Property of Procurement Process}

Construction material management is exposed to lots of exceptional influences and difficulty of accurate estimation since site conditions vary from site to site and construction progress may be hard to forecast accurately, depending on characteristics of the site. There are also lots of potential risks subject to changes in environment. Therefore, it is hard to plan material management in a long term and control materials in a systematic manner aligned to varying local and site conditions. On top of that, traffic congestion often delays material delivery in high-rise building construction sites located downtown. Construction materials are contracted, ordered, manufactured, delivered, moved to location, and installed to build. Speaking of tasks in detail of each step in the aforementioned flow, material quantity, construction schedule, packaging method, transportation arrangement and on-site moving method are determined at contracting step. In the following ordering and manufacturing steps, specific procurement approach and detailed production plan are defined. At transporting step, required quantity considering loss in storing and transportation/ on-site moving units is determined, part/material data is recorded and material specification/invoice is provided. In storing phase, storing location is confirmed and storing information is recorded and then materials are either stored or moved to location in accordance with stock after delivery or lift up upon delivery principle.

\section{2) Material Management Process of Finishing Material}

Problem of as-is material management process is such that most of the material control is exercised by head office and procurement data is not stored, making it difficult to make a timely decision. Also, focus of material management is placed only on material flow while interface to cost or schedule control is not properly emphasized.

Some general construction contractors have implemented project management information system (PMIS) or adopted supply chain management system (SCM) of manufacturing industry to improve effectiveness of construction control, but as data and information generates is not accumulated, improving construction control capability is not easy yet. Therefore, this research attempts to design a RFIDbased material tracking system capable of providing real time inputs to the end-to-end material management flow ranging from data generation to utilization and analysis with focuses on shipment of finishing material by supplier, tracking and locating such material on site.

\section{Finishing Material Selection}

\subsection{Background}

It may vary from building to building, but approximately 1,000 different materials are usually required in high-rise building (> 45 floors) construction projects. Especially, about 100 materials are required in structure work while the remaining 900 materials are used in finishing-work stage. Construction materials vary in type, shape and dimension and each material is procured, transported, delivered, moved and delivered in a different manner. Therefore, it is not practical to develop a material 
management plan considering all those parameters. Hence, several finishing materials that are easy to monitor with RFID material tracking system were selected in consideration of pre-conditions to application of RFID technology following literature reviews and interviews with industry experts.

\subsection{Selection}

Ahn(2003) proposed concepts of representative finishing materials to examine feasibility of finishing material moving plan in high-rise building construction and selected 9 representative finishing materials (gypsum board, stud, ceiling material, lightweight steel frame, rock wool, floor tile, stone, curtain wall and duct) [4]. As major finishing materials were already identified in a preceding study, we narrowed down on the scope of finishing materials application to this study from the 9 materials in consideration of inputs from the other experts.

After interviewing with experts over 10 representative finishing materials, interviewed project managers suggested that, given the known factors that may limit effectiveness of RFID technology such as material characteristics (radio interference), packaging and dimension and field requirements for RFID system, priorities be given to finished products that are not required to be assembled on site and materials shipped in boxes or pallets by suppliers to ensure effectiveness of RFID application. In that context, ceiling material shipped as packaged in boxes was selected as a candidate to which our RFID-assisted material tracking system model would be applied.

\subsection{Material Management Process of Ceiling Materials}

In consideration of the major concerns for application of RFID technology as described in the above and specific tasks of procurement process, type, size and packaging unit applicable to ceiling material, material tracking system model was developed.

\section{1) Procurement Process}

Materials manager procures materials in reference to basic parameters of material management such as delivery timing and stocking standard. Weekly plan is developed in a weekly working schedule meeting with supplier representatives and construction managers at site office and construction site manager forwards material management information to integrated logistics team to adjust material delivery order among construction sections and sends purchase order to supplier. Based on the purchase order, material supplier issues invoice where project site name, construction section, access point and supplier name.
Site materials manager confirms invoice and inspect delivered material (Fig. 2).

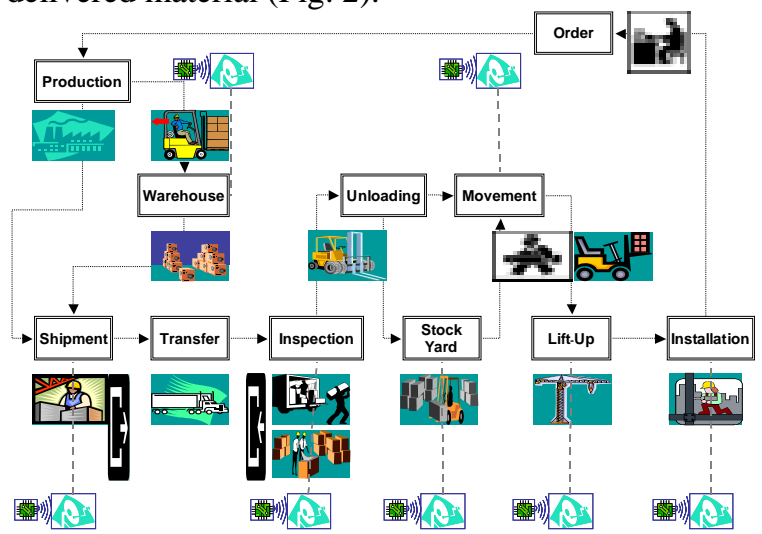

Figure 2. RFID Material Management Process Concept of Ceiling Materials

2) RFID Application of Material Tracking System Given the characteristics of finishing work, even materials of the same nature may have a variety of shapes or types, a lot of material data is required and linked to cost, such data needs to be assigned with unique ID when stored in tag. Given the considerable needs of large quantity of data for system operation, it may be sensible to store some information such as construction site name in tag without assigning unique ID so that it can be confirmed right away on the spot [5].

Table 2. Application Procedure of RFID system [3]

\begin{tabular}{|c|c|c|}
\hline Category & Requirements & Choice \\
\hline \multirow{2}{*}{$\begin{array}{c}\text { Change Tag } \\
\text { Contents }\end{array}$} & $\begin{array}{l}\text { Read Only: Cannot be altered } / 135 \mathrm{KHz} \sim 2.45 \mathrm{GHz} \text { frequency } \\
\text { range }\end{array}$ & $\sqrt{ }$ \\
\hline & Read Write: Rewritable(Can be altered) & \\
\hline \multirow{2}{*}{ Data Capacity } & Read Only: Store a limited amount of information(<2kbytes). & $\sqrt{ }$ \\
\hline & Read Write: High Memory(16 kbytes) & \\
\hline \multirow{2}{*}{ Data Format } & Storing all of the data on tag & \\
\hline & Programming a unique ID-number & $\sqrt{ }$ \\
\hline \multirow{2}{*}{ Data Security } & NO: Read Only & $\sqrt{ }$ \\
\hline & Yes: Read Write $(135 \mathrm{kHz}, 13.56 \mathrm{MHz}, 27.125 \mathrm{MHz}, 2.45 \mathrm{GHz})$. & \\
\hline \multirow{3}{*}{$\begin{array}{l}\text { Reading } \\
\text { Ranges \& Tag } \\
\text { Frequency }\end{array}$} & \begin{tabular}{|l|l|}
$0 \sim 1 \mathrm{~cm}$ & Close Coupling System $(30 \mathrm{MHz})$ \\
\end{tabular} & \\
\hline & \begin{tabular}{l|l}
\multirow{0}{*}{$0 \sim 1 \mathrm{~m}$} & $<135 \mathrm{KHz}, 6.75 \mathrm{MHz}, 13.56 \mathrm{MHz}, 27.125 \mathrm{MHz}, 2.45$ \\
& $\begin{array}{l}\text { GHz(contactless smart cards, material tracking, } \\
\text { animal identification, and timekeeping) }\end{array}$ \\
\end{tabular} & \\
\hline & \begin{tabular}{l|l}
$>1 \mathrm{~m}$ & $900 \mathrm{MHz}, 2.45 \mathrm{GHz}, 5.8 \mathrm{GHz}, 24.125 \mathrm{GHz}$ \\
& -Passive tags or Active tags
\end{tabular} & $\checkmark$ \\
\hline \multirow{2}{*}{$\begin{array}{c}\text { Metal } \\
\text { Inference }\end{array}$} & No: & $\sqrt{ }$ \\
\hline & Yes: metal may be & \\
\hline \multirow{2}{*}{$\begin{array}{l}\text { Reader: } \\
\text { Handheld or } \\
\text { Stationary }\end{array}$} & The handheld readers offer portability(Material management) & $\sqrt{ }$ \\
\hline & $\begin{array}{l}\text { Stationary devices offer a larger reading range(turnstile to enter } \\
\text { the jobsite, facility entrance) }\end{array}$ & \\
\hline \multirow{2}{*}{$\begin{array}{c}\text { Anti-collision } \\
\text { Capability }\end{array}$} & No: Do not consider anti-collision procedures & \\
\hline & $\begin{array}{l}\text { Yes: Other considerations relate to tags being spaced closely } \\
\text { together. }\end{array}$ & $\checkmark$ \\
\hline \multirow{2}{*}{$\begin{array}{l}\text { Frequency } \\
\text { Inference }\end{array}$} & No: Select most expedient frequency & \\
\hline & Yes: Identify and avoid conflicting transmission frequencies & $\sqrt{ }$ \\
\hline \multirow{2}{*}{$\begin{array}{l}\text { Integrated into } \\
\text { PMIS }\end{array}$} & No: & \\
\hline & $\begin{array}{l}\text { Yes: It is very important to have this RFID system compatible } \\
\text { with the PMIS(Project Management Information System) }\end{array}$ & $\sqrt{ }$ \\
\hline
\end{tabular}

Since working environment is not that favorable in most construction sites, passive type tags with reading range of $3 \sim 10 \mathrm{~m}$ may be adequate for finishing materials delivered in large quantity. Also finishing materials are usually delivered in large quantity to site at once, it can be difficult to read tags attached to packaging boxes as they are stocked close to each other. Therefore, program to be developed must be capable of preventing collision between data signals. Radio interference by other electro-magnetic waves should also be considered. Standardization of 
frequency ranges assigned to each RFID type are yet to be determined in Korea, but $900 \mathrm{MHz}$ believed to be adequate for material tracking system was selected tentatively for this research. Tabe 2 is a checklist filled out to develop finishing material procurement process utilizing RFID technology.

\subsection{RFID Material Tracking System Modeling}

1) Work Flow in Material Tracking System

In reference to RFID design checklist, boxpackaged finishing material procurement process and tag-stored data are identified in the following figure. In general, standardized products in great demands are delivered to site after being stocked in stockyard (warehouse) or right away if urgently needed. Given that, two site delivery flows were defined. In addition, lift up flow was also defined to have double track as some materials are stocked (assembled) on site and lifted up to floor while others are lifted up upon delivery to site.

This research adopted $900 \mathrm{MHz}$ passive R/O tag for RFID-assisted material tracking system model. As shown in the conceptual diagram of Figure 3 readers were not proposed for movement and lift up/stocking steps but applied to the other steps as in the material procurement process concept. Data inputs to the finishing material tracking system were defined in a series of interviews with site engineers.

Table 3. Entity \& Attribute of System

\begin{tabular}{|c|c|}
\hline Entity & Attribute \\
\hline Production & $\begin{array}{l}\text { Field ID, Field Name, Address, Product Date } \\
\text { Field Summary, Owner, Designer, Supervisor, Engineer, } \\
\text { Commencement Date, Project Schedule, Completion Date, } \\
\text { Phone No. }\end{array}$ \\
\hline $\begin{array}{c}\text { Supply } \\
\text { (Shipment \& } \\
\text { Warehouse) }\end{array}$ & $\begin{array}{l}\text { Material ID, Vehicle No., Vehicle Capacity, Driver Name, } \\
\text { Supply Date, Supplier Name, Invoice No., Material Transfer } \\
\text { Time, Gate No. Stockyard No. Recipient }\end{array}$ \\
\hline Supplier & Supplier Name, Mgr Name, Address, Tel No. \\
\hline Field & $\begin{array}{l}\text { Field ID, Field Name, Address, Field Summary, Owner, } \\
\text { Designer, Supervisor, Commencement Date, Completion } \\
\text { Date, Phone No. }\end{array}$ \\
\hline Buildi & Field ID, Building No., Zoning No. \\
\hline Floor & Field ID, Building No., Zoning No., Floor No. \\
\hline $\begin{array}{l}\text { Material } \\
\text { (Ceiling } \\
\text { Material) }\end{array}$ & $\begin{array}{l}\text { Material ID, Type, Size, Color, Unit, Installation, Building } \\
\text { No., Floor No. }\end{array}$ \\
\hline Production & Material ID, Product Name, Product Date, Related DWG. \\
\hline $\begin{array}{l}\text { Inspection \& } \\
\text { Unloading }\end{array}$ & $\begin{array}{l}\text { Vehicle No., Driver Name, Invoice No., Inspection Date, } \\
\text { Inspector Name, Stockyard No. Lift-up Qnty., Stockyard } \\
\text { Qnty. }\end{array}$ \\
\hline Lift-Up & $\begin{array}{l}\text { Field ID, Building No., Zoning No., Floor No., Material ID, } \\
\text { Lift-up Date, Lift-up Qnty., Sub-con Name, Hoist No., } \\
\text { Worker. Lift-up Method, Mgr Name, Engr Name }\end{array}$ \\
\hline Reservation & $\begin{array}{l}\text { Floor No., Supply schedule, Lift-up schedule, Install } \\
\text { Schedule, Material ID, Material Qnty., Lift-up Qnty., Hoist } \\
\text { No., Engr Name }\end{array}$ \\
\hline Stockyard & $\begin{array}{l}\text { Zoning No., Stockyard No., Material ID, Material Qnty., } \\
\text { Material Qnty., Inventory Qnty. Worker }\end{array}$ \\
\hline Order & $\begin{array}{l}\text { Field No., Building No., Zoning No., Gene-con Name, Engr } \\
\text { Name, Material ID, Material Qnty., Material Qnty., Supply } \\
\text { schedule, Supplier Name, Inventory Qnty. Project Schedule, } \\
\text { Cost ID, WBS ID, Work Package ID, Lead Time, Change } \\
\text { Order, Engr Name }\end{array}$ \\
\hline Gene-Con & Field No., Gene-con Name, Mgr Name, Engr Name, Tel No. \\
\hline Sub-Con & $\begin{array}{l}\text { Field No., Sub-con Name, Mgr Name, Tel No., Gene-con } \\
\text { Name }\end{array}$ \\
\hline
\end{tabular}

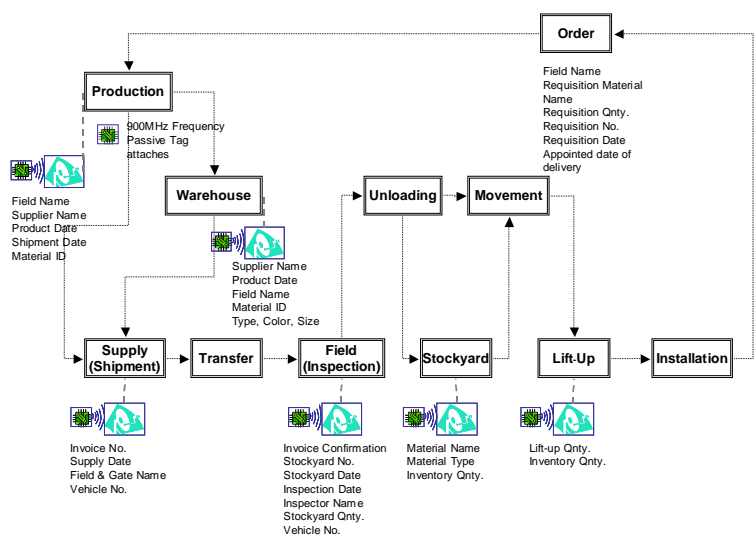

Figure 3. Supply and Moving Process for Material Tracking System

\section{System Modeling}

\subsection{Database Flow Diagram}

To develop a pilot material tracking system, following data flow as in Figure 4 was proposed. Data attributes of material management process was grouped by site manager, material engineer, manufacturer and material supplier and interface to scheduling information was defined in the data flow. Material code was derived from the Standard Product Breakdown Structure of MOCT and product code and supplier code were specified in the database.

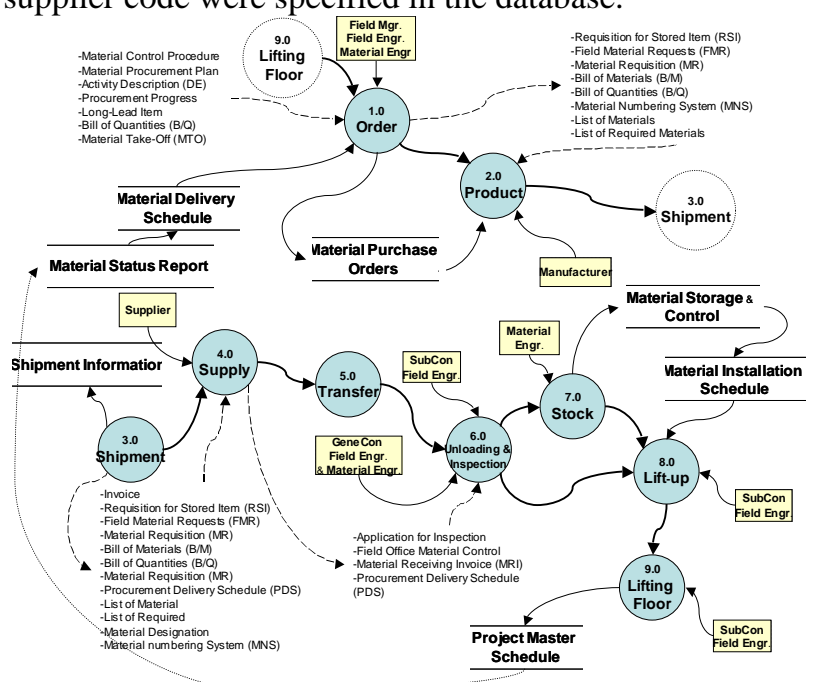

Figure 4. Database Flow Diagram of Material Tracking System

\subsection{Database Modeling}

Based on representative data attributes applicable to ceiling material tracking system development as in Table 3, data attributes were grouped per entity and workflow definition was transformed into database model (Figure 5). This research has simply focused on describing parameters required for implementation of RFID-assisted finishing material tracking system and effectiveness of RFID employed in material management system 
compared to that of conventional material management process has yet to be verified in specific site tests.

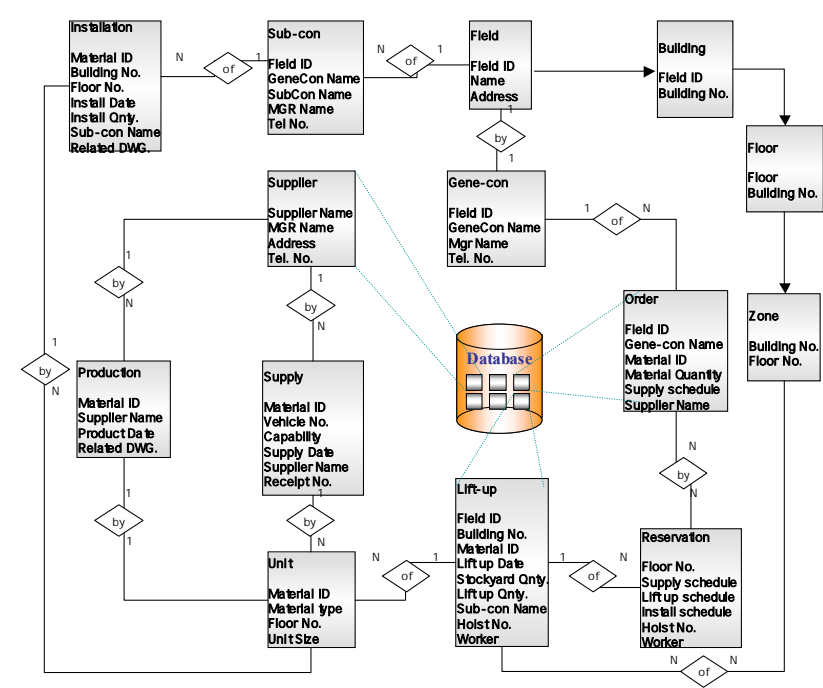

Figure 5. Database Model (Entity-Relationship)
University of Kentucky Civil Engineering Department, April 24, 2003

[5] CII, "Radio Frequency Identification Tagging". RFID Tagging Research Team-Research Summary 151-1, March 2001

\section{CONCLUSIONS}

Sensing technology is expected to bring considerable benefits to construction industry, but there are still potentials to be developed in terms of applying and utilizing it for specific purposes. While other industries are technically advancing at a rapid pace and trying to innovate manufacturing process, construction industry is still locked with conventional approaches and return on investment is not very high.

Construction industry should be reshaped by innovative technology platforms such as RFID. The finishing material tracking system proposed herein should be further refined and verified in the future so that it may provide a momentum for driving changes of construction industry and a drastic shift in mindsets of those engaged in construction industry is called for.

\section{REFERENCES}

[1] Ahn, Byung-Joo et al., "Development of the moving and procurement system for Just-in Time in the Building Construction", KJCEM, Vol. 4, No. 4, pp. 182-191., 2003

[2] Burcu Akinci, et al., "Utilizing Radio Frequency on Precast Concrete Components-Supplier's Perspective", Carnegie Mellon University, Pittsburgh, PA., 2003

[3] Edward J. Jaselskis et al., "Implementing Radio Frequency Identification in the Construction Process", ASCE, November 2003

[4] Mike Schneider, "Radio Frequency Identification (RFID) Technology and its Applications in the Commercial Construction Industry", Master's Thesis, 